\title{
Expression and characterization of Trichoderma reesei endoglucanase II in Pichia pastoris under the regulation of the GAP promoter
}

\author{
Kezia Abib Yerah Tjandra ${ }^{1}$, Kartika Sari Dewi ${ }^{2,}$, , Asrul Muhamad Fuad ${ }^{2}$, Trisanti Anindyawati \\ ${ }^{1}$ Department of Industrial Biotechnology, Brawijaya University, Jalan Veteran, Malang 165145, Indonesia \\ ${ }^{2}$ Research Centre for Biotechnology, Indonesian Institute of Sciences, Jalan Raya Jakarta-Bogor Km.46, Cibinong 16911, Indonesia \\ ${ }^{*}$ Corresponding author: kartika.sari.dewi@lipi.go.id
}

SUBMITTED 22 April 2020 REVISED 30 August 2020 ACCEPTED 7 October 2020

\begin{abstract}
Trichoderma reesei is known to be one of the organisms capable for producing various types of cellulase in high concentrations. Among these cellulases, the highest catalytic efficiency of endoglucanases II (EGII, EC 3.2.1.4) are considered important for industrial application. The characterization of the EGII is necessary since it is widely used in high-temperature reactions in the industries. In this study, the recombinant EGIl protein was expressed in Pichia pastoris and it has a molecular mass of approximately $52 \mathrm{kDa}$. Recombinant EGIl was purified using Ni-NTA affinity chromatography and characterized by SDS-PAGE and western blot analyses. The enzyme activity of recombinant EGIl was measured using the Nelson Somogyi method to determine its optimum $\mathrm{pH}$ and temperature. The result showed that the maximum EGII expression was achieved after $72 \mathrm{~h}$ of culture incubation. The crude enzyme has optimum activity at $\mathrm{pH} 5.0$, resulting in $16.3 \mathrm{U} / \mathrm{mL}$ and $14.6 \mathrm{U} / \mathrm{mL}$ activity at $40^{\circ} \mathrm{C}$ and $50^{\circ} \mathrm{C}$, respectively. While the purified enzyme gave the specific activity of $115.7 \mathrm{U} / \mathrm{mg}$ under the optimum condition. Finally, our study demonstrated that recombinant EGIl could retain the endoglucanase activity for $89 \%$ and $80 \%$ at $40^{\circ} \mathrm{C}$ and $50^{\circ} \mathrm{C}$, respectively.
\end{abstract}

KEYWORDS Endoglucanase II; GAP promoter; Trichoderma reesei; Pichia pastoris; Nelson-Somogyi assay

\section{Introduction}

Trichoderma reesei is a well-studied fungus that is capable of producing large amounts of various cellulases. This fungus secretes at least six types of cellulases that consist of two types of cellobiohydrolases and four endoglucanases (Knott et al. 2014). These enzymes are extensively used in several industries, such as laundry detergent, textile and pulp, paper industry, and potential for bioenergy production. Thereby, this fungus is industrially relevant to meet the target production level of cellulases. Nowadays, the engineering of cellulase into a highperformance enzyme for biomass hydrolysis and other industrial applications becomes the major research priority. However, various industrial processes and conditions (particularly in different temperature and $\mathrm{pH}$ conditions) remain a challenge. The cellulase excreted from $T$. reesei cannot withstand a long period of exposure at high temperature and $\mathrm{pH}$ during its reaction process, which leads to the leveling off of enzymatic activity (Akbarzadeh et al. 2014).

Among cellulases produced by $T$. reesei, endoglucanase II (EGII; EC 3.2.1.4) is predominant and showed the highest catalytic proficiency. The EGs activity of $T$. reesei is known to decrease about $55 \%$ when EGII was absent in the secretory complex of EGs (Qin et al. 2008; Boonvitthya et al. 2013). This evidence revealed that the presence of EGII is crucial for lignocellulosic biomass hydrolysis and other industrial applications. Several studies reported that EGII production and characteristic improvement were performed by improving the strain of secreting microorganisms, protein engineering, and recombination (Ito et al. 2004; Liang et al. 2011; Charoenrat et al. 2013). Thereby, there is still ample scope for improvement, particularly to produce EGII in a heterologous expression system to facilitate protein engineering work. Several heterologous expression has been carried out to produce endoglucanases in various host microorganisms, including Escherichia coli, Yarrowia lipolytica, Saccharomyces cerevisiae, and Pichia pastoris (Nakazawa et al. 2008; Qin et al. 2008; Boonvitthya et al. 2013; Akbarzadeh et al. 2014). Yeast is commonly used for its ability to increase protein stability since the glycosylation process has occurred. In consequence, the structural and thermal stability of protein may increase due to the covalent bond formation. The covalent bond formation causes less dynamic fluctuation and reduces protein molecules' flexibility (Qin and Qu 2014).

Pichia pastoris has negligible native protein produc- 
tion levels, which helps for easier purification of recombinant protein (Macauley-Patrick et al. 2005). It has also been proven that the expression system promotes economically effective production of recombinant protein as it does not need complex medium and condition (Safder et al. 2018). The expression of a foreign gene in P. pastoris includes three main steps: (a) insertion of the foreign gene into an expression vector; (b) introduction of the expression vector into the expression host, $P$. pastoris; and (c) the selection of potential strains for foreign gene expression (Macauley-Patrick et al. 2005). The gene encoding EGII (egII gene) from $T$. reesei was successfully inserted into an expression vector and introduced into $P$. pastoris genome. In this study, the high-expression transformant with high endoglucanase activity was selected for further steps. The expression of recombinant EGII was regulated under glyceraldehyde-3-phosphate dehydrogenase (GAP) constitutive promoter in the fed-batch fermentation process. Recombinant EGII produced was then characterized for the determination of its optimum $\mathrm{pH}$, temperature, and thermal stability.

\section{Materials and Methods}

\subsection{Strain and plasmid}

Pichia pastoris SMD1168H purchased from Invitrogen (USA) was used as an expression host. Constructed plasmid pLIPI-TrCel5A ordered at ATUM (USA) used as an expression vector for $P$. pastoris transformant carrying egII gene from $T$. reesei was available at Research Center for Biotechnology, Indonesian Institute of Sciences.

\subsection{Colony selection}

Pichia pastoris transformant from glycerol stock was streaked in YPD agar (1\% w/v yeast extract, 2\% w/v peptone, $2 \% \mathrm{w} / \mathrm{v}$ dextrose, $1.8 \%$ bacteriological agar) medium containing zeocin $(500 \mu \mathrm{g} / \mathrm{mL})$ and ampicillin $(100 \mu \mathrm{g} / \mathrm{mL})$ antibiotics (Invitrogen, USA) and incubated at $28^{\circ} \mathrm{C}$ for $36 \mathrm{~h}$.

Six colonies were selected from the selection medium and characterized by colony PCR. Specific primers, namely MF $\alpha-F P 1$ (5'ATGAGATTCCCATCTATTTTCACCGCTGTCT-

3') and TrCel5A-RP (5'-
GAGCGGGGGATATACTTTGGAAGTAACACAA-3'), were used to detect the inserted gene in the yeast genome. PCR was performed as follows: initial denaturation at $95{ }^{\circ} \mathrm{C}$ for $5 \mathrm{~min}$; 30 cycles of denaturation at $95{ }^{\circ} \mathrm{C}$ for $30 \mathrm{~s}$, annealing at $55^{\circ} \mathrm{C}$ for $40 \mathrm{~s}$ and extension at $72{ }^{\circ} \mathrm{C}$ for $40 \mathrm{~s}$, then final extension at $72{ }^{\circ} \mathrm{C}$ for $5 \mathrm{~min}$. The amplified fragments were then analyzed using $1 \%$ agarose gel electrophoresis.

The colonies were then confirmed for their expression of EGII, measured by a plate diffusion assay according to the method proposed by Ratnakomala et al. (2019). Ten microlites of each transformant cultures were added into agar wells containing $0.5 \%(\mathrm{w} / \mathrm{v})$ carboxyl methylcellu- lose (CMC) and incubated for $3 \mathrm{~d}$ at $30^{\circ} \mathrm{C}$. Finally, plates were stained using $1 \%$ Congo Red solution for $15 \mathrm{~min}$ for color development, followed by washing the plate with 1 $\mathrm{M}$ sodium chloride solution to detect halo zones. The diameter of the halo zones was measured and documented. Transformants with bigger halo zones were selected for further analysis.

Selected transformants were tested for their endoglucanase activity. The activity was measured by NelsonSomogyi (NS) method using CMC as a substrate, according to the reference by Gusakov et al. (2011). About 160 $\mu \mathrm{L}$ of $6.25 \mathrm{mg} / \mathrm{mL}$ CMC in $0.1 \mathrm{M}$ acetate buffer ( $\mathrm{pH}$ 5.0) and $40 \mu \mathrm{L}$ culture supernatant were preheated at $50^{\circ} \mathrm{C}$ for $5 \mathrm{~min}$. Both were mixed and heated at $50{ }^{\circ} \mathrm{C}$ for another 10 min. Zero-point two milliliters of copper tartrate was added into the mixture to stop the reaction, and then the assay mixture was incubated in boiling water for $40 \mathrm{~min}$. The mixture was allowed to decrease the temperature to $25{ }^{\circ} \mathrm{C}$ (room temperature), then $0.2 \mathrm{~mL}$ of arsenomolybdate was added and incubated at room temperature for 10 min. One point four milliliters of a mixed solution and 0.4 $\mathrm{mL}$ of acetone was added into the assay mixture and then centrifuged at 13,000 rpm for $1 \mathrm{~min}$. The optical density was measured using a spectrophotometer at $\lambda=610 \mathrm{~nm}$ to estimate the quantity of reducing sugars produced in the assay mixture. One enzyme activity unit was defined as the amount of enzyme-producing one $\mu$ mol of reducing sugar per min under assay conditions (Jin et al. 2011).

\subsection{Culture condition of endoglucanase II expression in Pichia pastoris}

The pre-culture of each selected colonies was prepared into $2 \mathrm{~mL}$ YPD medium containing $100 \mu \mathrm{g} / \mathrm{mL}$ ampicillin and $100 \mu \mathrm{g} / \mathrm{mL}$ zeocin, then incubated at $28{ }^{\circ} \mathrm{C}$ for $2 \mathrm{~d}$. One milliliter of pre-culture was added into $19 \mathrm{~mL}$ YPD medium containing $100 \mu \mathrm{g} / \mathrm{mL}$ ampicillin without zeocin in an Erlenmeyer flask and incubated at $28{ }^{\circ} \mathrm{C}$ for $4 \mathrm{~d}$ at $250 \mathrm{rpm}$. Fed-batch culture, including sampling, was carried out every $24 \mathrm{~h}$ intervals by withdrawing $4 \mathrm{~mL}$ of culture supernatant, along with the addition of $4 \mathrm{~mL}$ of $5 \times$ YPD medium to return the initial medium volume. The batch culture was only involving sampling every $24 \mathrm{~h}$ intervals by withdrawing $4 \mathrm{~mL}$ culture supernatant without the addition of YPD media.

\subsection{SDS-PAGE and Western Blot}

Sample preparation for SDS-PAGE analysis was done following the reference by Koontz (2014). One milliliter of culture from sampling was centrifuged in 12,000 rpm to separate its pellet and supernatant. The sample supernatant was added with $150 \mu \mathrm{L}$ of $100 \%$ TCA, then vortex to homogenize. The sample was incubated at $4{ }^{\circ} \mathrm{C}$ overnight to allow protein precipitation, then centrifuged at 12,000 rpm for $10 \mathrm{~min}$ to allow separation between supernatant and precipitated protein. The supernatant was removed without disrupting the pellet. The pellet was washed using $200 \mu \mathrm{L}$ of acetone, followed by centrifugation at 12,000 for $10 \mathrm{~min}$. The step of washing the pellet with acetone 
was repeated twice to ensure no more TCA residue was left. Pellet was allowed to dry to remove the acetone, then added with $15 \mu \mathrm{L}$ of $5 \times$ SDS-PAGE loading buffer and being heated for $10 \mathrm{~min}$ in boiling water. Samples then analyzed by 15\% SDS-PAGE gel using $90 \mathrm{~V}$ for $80 \mathrm{~min}$ to run the samples. The molecular mass was estimated from the migration distance in comparison with the prestained protein molecular weight marker (Thermo Scientific, USA).

Western blot was performed by electrotransfer the bands from acrylamide gels onto a nitrocellulose membrane at $90 \mathrm{~V}$ for $2 \mathrm{~h}$. The membrane was blocked using a $10 \mathrm{~mL}$ blocking agent containing 1\% BSA, then incubated for $1 \mathrm{~h}$ with gentle shaking at room temperature. The 5 $\mu \mathrm{L}$ of KPL HisDetector Nickel-HRP (SeraCare, USA) was added directly into the block solution, and incubation was continued for $1 \mathrm{~h}$ with gentle shaking. The membrane was washed three times with TBS solution containing $0.05 \%$ v/v Tween-20, each time for $5 \mathrm{~min}$. Finally, the detection was done by adding $5 \mathrm{~mL}$ KPL TMB to visualize bands of interest (Thermo Scientific, USA).

\subsection{Purification of recombinant endoglucanase II}

The cell-free medium culture was harvested using centrifugation after $72 \mathrm{~h}$ of incubation and purified manually using Ni-NTA sepharose affinity chromatography column (Thermo Fisher Scientific, Massachusetts, U.S.). One milliliter of column material was washed with a five-bed volume of $20 \%$ ethanol, then washed with aquadest with the same volume. The column was then equilibrated with a five-bed volume of $50 \mathrm{mM}$ PBS buffer ( $\mathrm{pH}$ 7.4). A threebed volume of crude EGII sample was added and incubated at $4{ }^{\circ} \mathrm{C}$ for $2 \mathrm{~h}$. The sample was allowed to flow through the column and collected in an Eppendorf tube, labeled as a flow-through fraction. The column was then being washed with a three-bed volume of $50 \mathrm{mM} \mathrm{PBS} \mathrm{pH}$ 7.4. Finally, a three-bed volume of an elution buffer containing $250 \mathrm{mM}$ of imidazole was added into the column. Each $250 \mu \mathrm{L}$ was collected as one fraction in a $1.5 \mathrm{~mL}$ centrifuge tube. Then proteins from collected fractions were then analyzed using 15\% SDS-PAGE gel to identify which fraction contained purified EGII. The protein concentration was estimated using a Bovine Serum Albumin (BSA) standard curve following Carter's method (2013). The electropherogram of SDS-PAGE containing EGII proteins and a series of BSA with known concentration were subjected to Image J 1.53e software (Rasband, 1997-2018). By calculating the area under the curve (AUC) of the BSA protein band, the linear regression equation was made. The AUC of EGII was analyzed, and the value was entered into the equation to get the concentration of recombinant EGII.

\subsection{Characterization of recombinant endoglucanase II}

Characterization was done by following the NS method according to the reference by Gusakov et al. (2011) as mentioned in section 2.2. The optimum $\mathrm{pH}$ and temperature for enzymatic activity assay were established using the standard procedure, according to the reference by Bajaj et al.
(2009). To determine pH's effect on enzyme activity, various buffers including citrate, acetate, phosphate, tris, bicarbonate, and carbonate buffers with $\mathrm{pH} \mathrm{3,} \mathrm{5,} \mathrm{6.8,} \mathrm{8,} \mathrm{9,}$ and 10 respectively were used. To determine the optimum temperature of recombinant endoglucanase, the temperature used was varied $\left(40^{\circ} \mathrm{C}, 50^{\circ} \mathrm{C}, 60^{\circ} \mathrm{C}\right.$ and $\left.70^{\circ} \mathrm{C}\right)$ under standard assay conditions. One percent of the CMC solution was used as a substrate to determine optimum $\mathrm{pH}$ and temperature. To determine the thermal stability of recombinant EGII, equal quantities of purified EGII were preincubated for $15,30,45$, and 60 min at optimum temperature and $\mathrm{pH}$, which already pre-determined. After preincubation, enzyme activities were measured using standard assay conditions. Enzyme activity can be calculated by using the formula as the following: Endoglucana seactivity $(U / \mathrm{mL})=\frac{\text { glucoseconcentration }(\mathrm{mg} / \mathrm{mL}) \times \text { dilution factor } \times 1000}{t(\mathrm{~min}) \times \text { Molecularweightofglucose }}$

Whereas enzyme-specific activity can be calculated by using the following formula:

Specificactivity $(U / m g)=\frac{\text { enzymeactivity }(U / m L)}{\text { proteinconcentration }(\mathrm{mg} / \mathrm{mL})}$

\section{Results and Discussion}

\subsection{Selection of recombinant clones}

A study conducted by (Sivashanmugam et al. 2009) suggested that long-time storage of glycerol stock utilized for pre-culture preparation often leads to low-yield protein expression, although the colony used was known to previously produce a high yield of the target protein. Therefore, colony selection should be re-conducted. In this study, we did colony selection from glycerol stock using colony PCR followed by enzyme activity and expression screening.

The recombinant clones from glycerol stock were spread on YPD plates containing zeocin $(500 \mu \mathrm{g} / \mathrm{mL})$ and ampicillin $(100 \mu \mathrm{g} / \mathrm{mL})$. Six random recombinant clones were selected for screening after incubation at $28^{\circ} \mathrm{C}$ for $36 \mathrm{~h}$. Colony PCR was performed using specific primers to detect the presence of the egII gene in transformant colonies. pLIPI-TrCel5A plasmid carrying egII gene was used as a template for positive control while $P$. pastoris SMD1168H nontransformed colony was used for negative control. The amplified products were visualized on an agarose gel as seen in Fig. S1, and were approximately $625 \mathrm{bp}$ in length. The result ensures that all selected transformants were inserted with egII gene.

TABLE 1 Average of halo zones and enzyme activity of clone 1-6.

\begin{tabular}{lll}
\hline Colony no. & Average of halo zones $(\mathrm{cm})$ & Enzyme activity $(\mathrm{U} / \mathrm{ml})$ \\
\hline 1 & 2.98 & 8.568 \\
2 & 2.65 & 7.096 \\
3 & 2.62 & 7.498 \\
4 & 2.65 & 6.570 \\
5 & 0.92 & 4.165 \\
6 & 0.77 & 6.540 \\
\hline
\end{tabular}




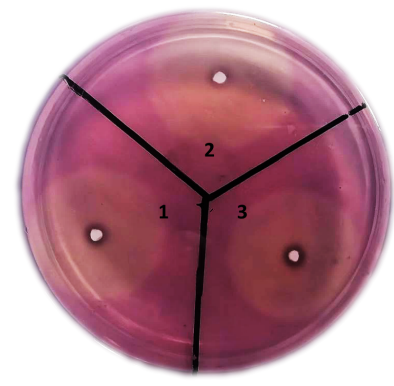

(a)

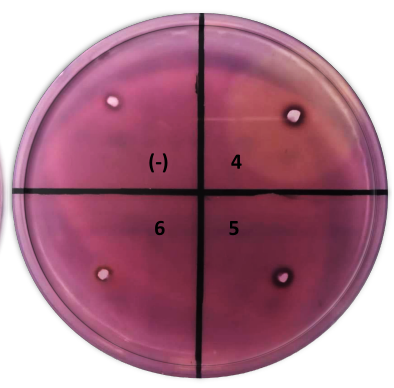

(b)
FIGURE 1 Agar well diffusion assay showing the enzymatic activity of six transformants and a control. (a) Agar well diffusion result by clone 1-3 (b) Agar well diffusion result by clone number 4-6 and a non-transformant (-).

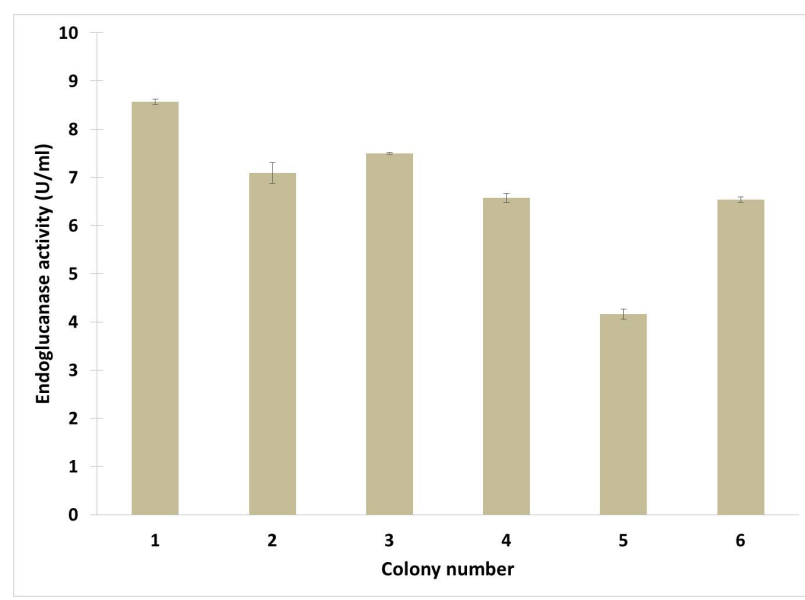

FIGURE 2 Endoglucanase activity assay of six transformant colonies. Values are averages of duplo assays, bars indicate SD.

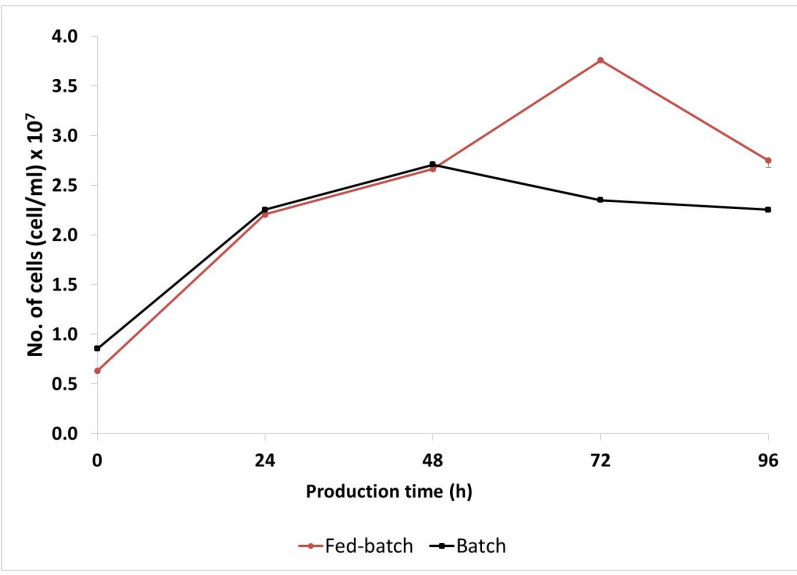

FIGURE 3 Comparison of fed-batch and batch production against a number of cells. Values are averages of duplo assays; bars indicate SD.

Colony selection was then continued with a qualitative and quantitative enzymatic assay, namely plate diffusion and NS assay. In plate diffusion assay, clone selection was based on the ratio between well and halo zone diameter. Whereas in NS assay, clone selection was based on the activity of EGII to breakdown CMC and produce reducing sugars, by which the reducing sugars will react with the
NS reagent. CMC was chosen as the substrate as it exhibits an amorph structure suitable for the hydrolysis mechanism by EGII (Biswas, 2014). This study showed that EGII was successfully expressed in all selected clones, as indicated by the halo zone formation. Clones 1-4 have a higher halo zone diameter, among others (Table 1 and Figure 1). Recombinant clones were then selected by determining their enzyme activities using the NS method (Table 1 and Figure 2). From those analyses, clones 1-3 showed higher endoglucanase activity compared to other colonies.

\subsection{Heterologous expression of Endoglucanase II by re- combinant clones in YPD media}

The expression profile of recombinant protein produced by six recombinant clones in YPD media was analyzed through 15\% SDS-PAGE gel after $96 \mathrm{~h}$ of incubation, including sampling every $24 \mathrm{~h}$ intervals (Supplementary Figure 2). Clone 2 was chosen for further expression analysis as it showed the thickest band of interest at a size of around $50 \mathrm{kDa}$ with lesser non-target bands. Moreover, clone 2 also showed a high enzymatic activity, which refers to plate diffusion and NS assay (Figure 1 and Figure 2). Clone 2 was then used for recombinant EGII production through fed-batch and batch fermentation (Figure 3). The production of recombinant EGII through fedbatch and batch fermentation was done to compare both methods and know which method is less time-consuming and produce a higher level of the target protein. Feeding was included in fed-batch fermentation by adding a new $5 \times$ YPD medium right after sampling, whereas batch fermentation only included sampling. The maximum number of cells achieved through fed-batch fermentation was $3.76 \times 10^{7}$ cells $/ \mathrm{mL}$ after $72 \mathrm{~h}$ of incubation. Meanwhile, the maximum number of cells achieved through batch fermentation was only $2.71 \times 10^{7}$ cells/mL after $48 \mathrm{~h}$ of incubation. The protein expression was done through fedbatch fermentation (Figure 4a) showed a thicker band of interest in each $24 \mathrm{~h}$ intervals compared to batch fermentation (data not shown). More protein bands were present in the protein expression profile from batch fermentation with less than $50 \mathrm{kDa}$ in size. Macauley-Patrick et al. (2005) suggest that the secreted recombinant proteins can be proteolytically degraded in the culture medium. This might happen due to cell-bound proteases, extracellular proteases, and/or intracellular proteases from lysed cells. The problems due to proteolysis can be foreseen in the recombinant protein production: (a) reduction of product yield when product is degraded, and (b) reducing biological activity when the product is truncated. In this study, protease production may occur due to the insufficiency of nutrients that lead to cell lysis. In comparison, fed-batch fermentation supplied enough nutrients added during production periods, which promoted optimal growth of culture and higher protein expression (Hadiyanto et al. 2013). Figure 4a showed that $P$. pastoris expressed the highest concentration of recombinant EGII after $72 \mathrm{~h}$ of incubation. Thereby, fed-batch fermentation for $72 \mathrm{~h}$ of incubation was used for further production of recombinant EGII. 

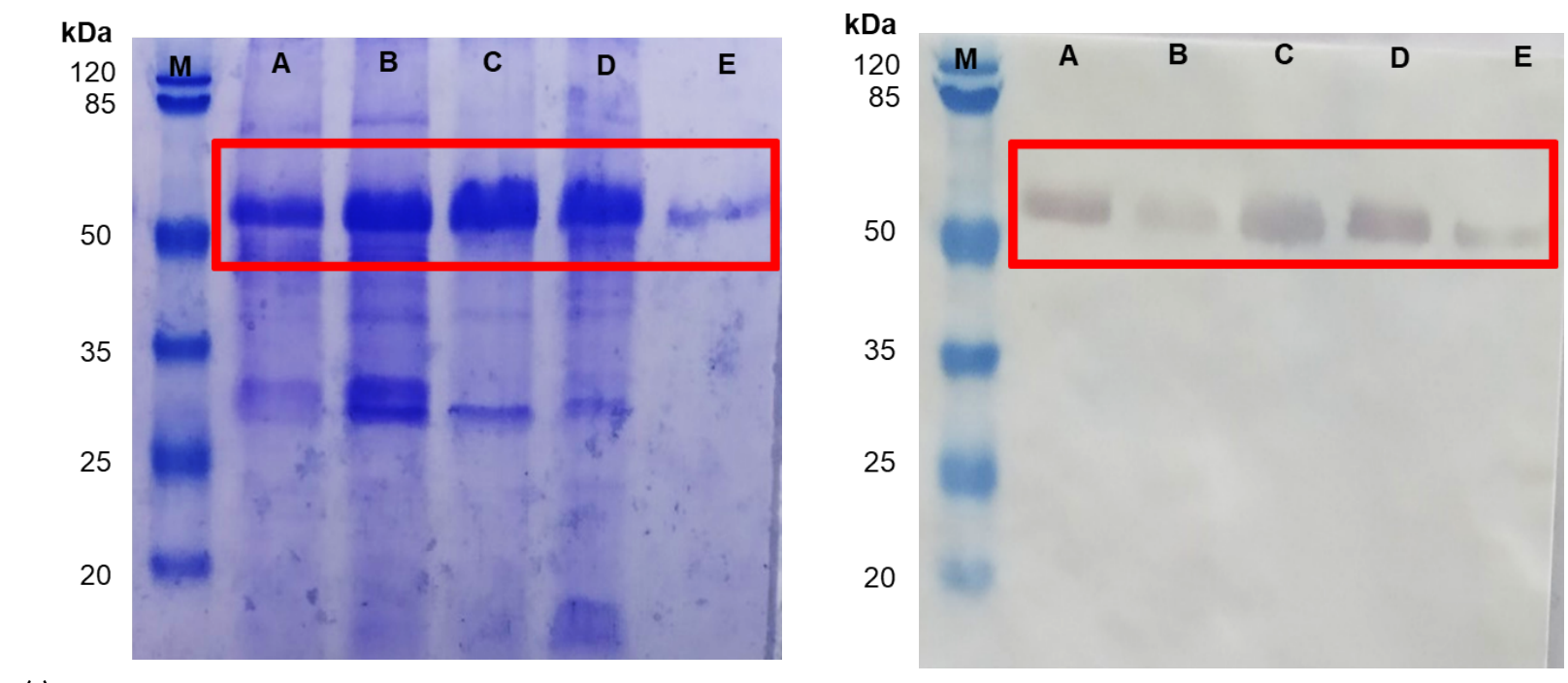

(a)

(b)

FIGURE 4 Expression and confirmation of endoglucanase II by clone 2. (a) SDS-PAGE analysis and (b) Western Blot confirmation of recombinant EG II. Lanes: (M) Protein molecular weight marker; (1-4) protein expression after $24 \mathrm{~h}, 48,72 \mathrm{~h}$ and $96 \mathrm{~h}$ respectively; (5) purified protein.

The expression profile of recombinant EGII by clone 2 every 24 h intervals was visualized through SDS-PAGE analysis (Figure 4a). The maximum expression of recombinant EGII was reached after $72 \mathrm{~h}$ with $3.49 \mathrm{mg} / \mathrm{L}$ protein secreted from $20 \mathrm{~mL}$ of fermentation culture. The growth of transformants reached stationary phase after 72 $\mathrm{h}$; thereafter, it entered the death phase. The estimated molecular mass of recombinant EGII was $52 \mathrm{kDa}$. EGII is a glycoprotein with 397 amino acids and has a molecular weight of $40 \mathrm{kDa}$ without glycosylation (Garvey et al. 2014). However, its molecular weight may increases up to $48 \mathrm{kDa}$ with native glycosylation done by $T$. reesei (Akbarzadeh et al. 2014). Sun et al. (2018) reported that the expression system by $P$. pastoris might increase up to 4 $\mathrm{kDa}$ of molecular weight due to glycosylation. In this study, the SDS-PAGE analysis of recombinant EGII protein expressed in $P$. pastoris showed a thick band with a slightly larger molecular mass than that of native EGII from $T$. reesei. However, there was not enough evidence to show that the increase in molecular mass is due to glycosylation. Treatment of recombinant EGII protein with endoglycosidase $\mathrm{H}$ may be required as supporting data to signify if glycosylation takes place.

\subsection{Purification and confirmation of recombinant en- doglucanase II}

The culture supernatant was purified manually using NiNTA sepharose resin. The column was eluted with an isocratic buffer containing $250 \mathrm{mM}$ imidazole to release the recombinant protein bound to the resin. All fractions collected were analyzed using SDS-PAGE. Among 12 elution fractions collected, the elution fraction 3 was known to have the thickest band of interest, indicating the highest concentration of purified protein (data not shown). All samples collected from sampling for each $24 \mathrm{~h}$ and elu- tion fraction 3 were analyzed using SDS-PAGE followed by Western blot to confirm the recombinant EGII protein (Figure $4 \mathrm{~b}$ ). The result exhibited a single band of $52 \mathrm{kDa}$ for each lane, which corresponds to a theoretical molecular mass of EGII recombinant proteins expressed in $P$. pastoris (Bai et al. 2016). The concentration of purified recombinant EGII was then quantified using a BSA standard curve followed by ImageJ analysis, resulting in 0.21 $\mathrm{mg} / \mathrm{mL}$ of purified EGII.

\subsection{Characterization of recombinant endoglucanase II}

The endoglucanase activity of recombinant EGII was assayed at different $\mathrm{pH}(3.0,5.0,6.8,8.0,9.0,10.0)$. The results showed that the recombinant EGII exhibited optimum activity at $\mathrm{pH} 5.9$ (Figure 5). Activity above $\mathrm{pH}$ 8.0 was negligible as it did not show enzymatic activity. The native endoglucanase by $T$. reesei also showed the same optimum pH (Li et al. 2013). The study conducted by Boonvitthya et al. (2013) revealed that the production of crude EGII in P. pastoris was around $10 \mathrm{U} / \mathrm{ml}$ under a controlled condition with the optimum $\mathrm{pH}$ at 5 to 6 and the temperature of $40-60^{\circ} \mathrm{C}$.

Endoglucanase activity measurement was using various temperatures ranging from $30{ }^{\circ} \mathrm{C}$ to $70^{\circ} \mathrm{C}$. The optimum temperature was found to be $40^{\circ} \mathrm{C}$ to $50^{\circ} \mathrm{C}$, as shown in Figure 6. Native endoglucanase also showed a similar range of optimum temperature, which was at $45^{\circ} \mathrm{C}$ to 55 ${ }^{\circ} \mathrm{C}$ (Kamal et al. 2017). The effect of temperature optimum on enzyme stability is shown in Figure 6. Pre-incubation was done at $40{ }^{\circ} \mathrm{C}$ and $50{ }^{\circ} \mathrm{C}$ with different time intervals up to $60 \mathrm{~min}$. About $89 \%$ of endoglucanase activity was retained at $40{ }^{\circ} \mathrm{C}$ after $60 \mathrm{~min}$, and more than $80 \%$ of endoglucanase activity was retained after $60 \mathrm{~min}$ at $50{ }^{\circ} \mathrm{C}$ (Figure 7). Based on the literature, native EGII secreted from $T$. reesei retained $60 \%$ of its enzymatic activity at 50 


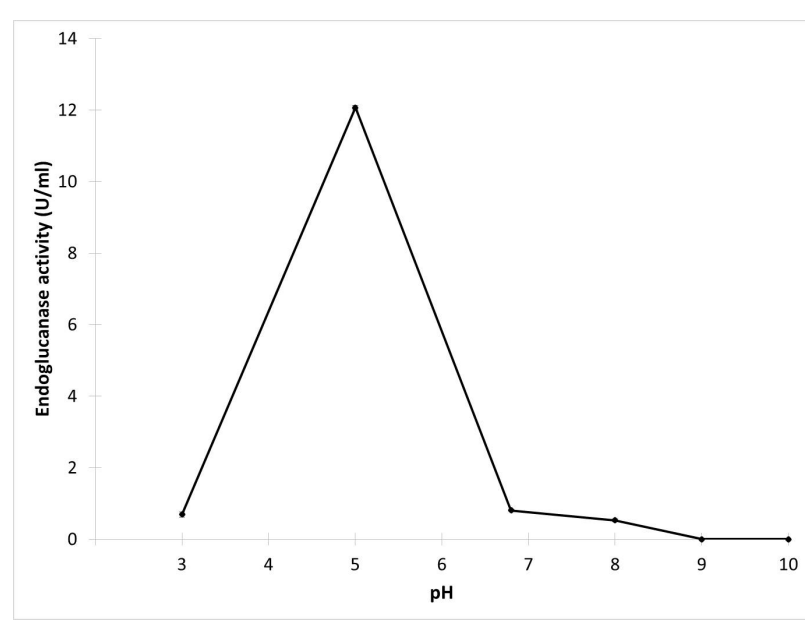

FIGURE 5 Optimum pH determination of endoglucanase II by clone 2. Values are averages of duplo assays; bars indicate SD.

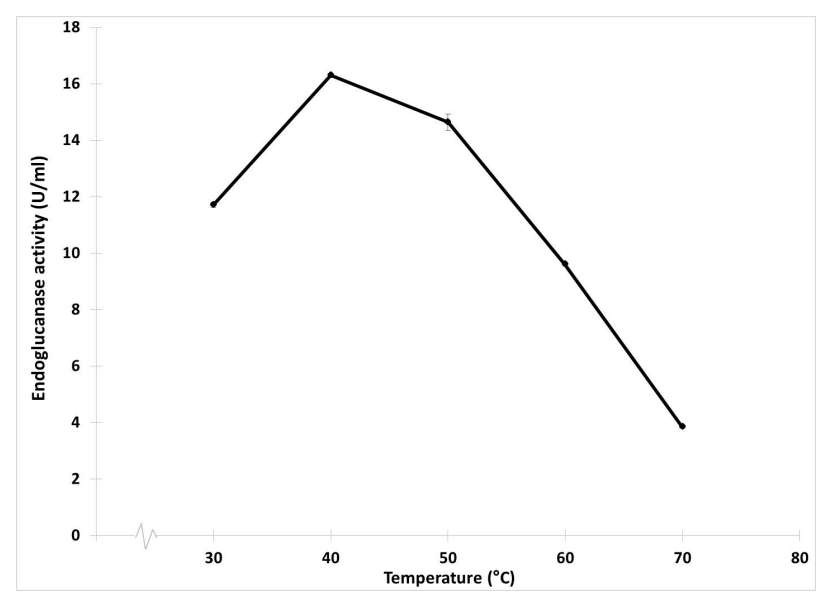

FIGURE 6 Temperature optimum determination of endoglucanase II by clone 2 . Values are averages of duplo assays; bars indicate SD.

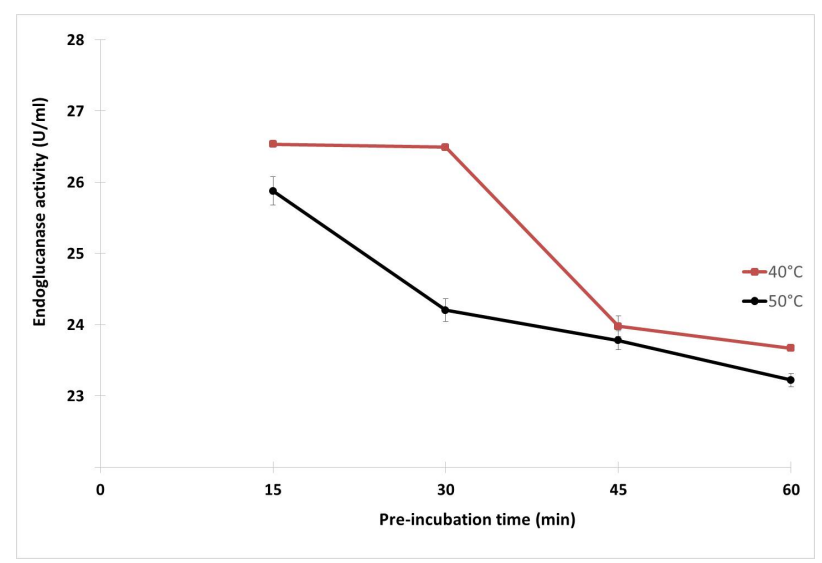

FIGURE 7 Legend for Figure 7: Thermal stability determination of recombinant Endoglucanase II by clone 2. Temperature used were at $40^{\circ} \mathrm{C}$ (red) and $50^{\circ} \mathrm{C}$ (black). Values are averages of duplo assays; bars indicate SD.

${ }^{\circ} \mathrm{C}$ after 40 min of incubation (Kamal et al. 2017). This evidence indicated the thermal stability of our recombinant EGII is slightly improved compared to native EGII derived from $T$. reesei as it can retain $80 \%$ endoglucanase activity after incubation at $50{ }^{\circ} \mathrm{C}$ for $60 \mathrm{~min}$.

The result of the thermal stability assay obtained was slightly lower than the study conducted by Samanta et al. (2012), which showed that recombinant EGII could retain relative endoglucanase activity up to $90 \%$ at $50{ }^{\circ} \mathrm{C}$. However, this study reported that purified EGII protein showed $24.3 \mathrm{U} / \mathrm{mL}$ of enzyme activity after pre-incubation at 50 ${ }^{\circ} \mathrm{C}$ in $\mathrm{pH}$ 5.0, which gave the specific activity of 115.7 $\mathrm{U} / \mathrm{mg}$. The specific activity of our recombinant EGII is higher than the result reported by using the E. coli expression system (Nakazawa et al. 2008).

N-glycosylation, a post-translational modification generally occurred in fungi, has important roles in enzyme stability. A study conducted by Han et al. (2020) demonstrated that the addition of N-glycosylation at particular amino acid sites has successfully increased the thermal stability of recombinant endoglucanase in $P$. pastoris. Optimized stabilization is associated with entropy which mostly dependent on glycosylation sites position (Shental-Bechor and Levy 2008). Generally, glycans attached to flexible regions within random coils would restrict the conformational space and promote entropic reduction to increase conformational stability at high temperatures (Dotsenko et al. 2016; Adney et al. 2009). This additional targeted N-glycosylation was deserved to be adopted in our future study to improve the thermal stability of our recombinant EGII.

Optimization of fermentation is also required to improve the expression of $P$. pastoris by exploring various carbon and nitrogen sources to enhance microbial growth and protein expression. Further study to maintain a specific growth rate is also highly suggested by implementing a short carbon-starving period through an exponential feeding strategy.

\section{Conclusions}

Recombinant EGII proteins were successfully expressed in the P. pastoris expression system with an optimum incubation time of $72 \mathrm{~h}$ using fed-batch fermentation. Characterization of recombinant EGII using SDS-PAGE and Western blot analyses showed that the EGII protein has a molecular weight of approximately $52 \mathrm{kDa}$. The enzymatic assay demonstrated that the crude enzyme has optimum activity at $\mathrm{pH}$ 5.0, which results in 16.3 and 14.6 $\mathrm{U} / \mathrm{mL}$ activity at a temperature of $40{ }^{\circ} \mathrm{C}$ and $50{ }^{\circ} \mathrm{C}$, respectively. The specific activity of recombinant EGII resulted in $115.7 \mathrm{U} / \mathrm{mg}$ in its optimum $\mathrm{pH}$ and temperature. Moreover, recombinant EGII can maintain $89 \%$ of its endoglucanase activity at $40{ }^{\circ} \mathrm{C}$ and more than $80 \%$ at $50{ }^{\circ} \mathrm{C}$ for $60 \mathrm{~min}$, indicating the improvement in thermal stability compared to native EGII derived from $T$. reesei.

\section{Acknowledgments}

This study was supported by cooperation research between Indonesian Institute of Sciences (LIPI) and PT. Pertam- 
ina (Persero), FY 2018-2019. We would like to acknowledge Muhammad Nugrah F. for his contribution during the study, including the experiment of batch fermentation.

\section{Authors' contributions}

KAYT - practical works, analysis and data interpretation, article drafting, KSD - design of the study, practical works, analysis and data interpretation, article drafting, AMF and TA - conception and design of the study. All authors read and approved the final version of the manuscript.

\section{Competing interests}

The authors declare no competing interest.

\section{References}

Adney WS, Jeoh T, Beckham GT, Chou YC, Baker JO, Michener W, Brunecky R, Himmel ME. 2009. Probing the role of $\mathrm{N}$-linked glycans in the stability and activity of fungal cellobiohydrolases by mutational analysis. Cellulose. 16(4):699-709. doi:10.1007/s10570-009-9305-1.

Akbarzadeh A, Ranaei Siadat SO, Motallebi M, Zamani MR, Barshan Tashnizi M, Moshtaghi S. 2014. Characterization and high level expression of acidic endoglucanase in Pichia pastoris. Appl Biochem Biotechnol. 172(4):2253-2265. doi:10.1007/s12010013-0672-6.

Bai R, Zhang Y, Wang C, Zhang F, Zhang Z, Sun F, Zhang Z. 2016. Gene optimization and efficient expression of Trichoderma reesei Cel5A in Pichia pastoris. Shengwu Gongcheng Xuebao 32(10):13811394. doi:10.13345/j.cjb.160017.

Bajaj BK, Pangotra H, Wani MA, Sharma P, Sharma A. 2009. Partial purification and characterization of a highly thermostable and $\mathrm{pH}$ stable endoglucanase from a newly isolated Bacillus strain M-9. Indian J Chem Technol. 16(5):382-387.

Boonvitthya N, Bozonnet S, Burapatana V, O’Donohue MJ, Chulalaksananukul W. 2013. Comparison of the heterologous expression of Trichoderma reesei endoglucanase II and cellobiohydrolase II in the yeasts Pichia pastoris and Yarrowia lipolytica. Mol Biotechnol. 54(2):158-169. doi:10.1007/s12033-012-95570 .

Charoenrat T, Khumruaengsri N, Promdonkoy P, Rattanaphan N, Eurwilaichitr L, Tanapongpipat S, Roongsawang N. 2013. Improvement of recombinant endoglucanase produced in Pichia pastoris KM71 through the use of synthetic medium for inoculum and $\mathrm{pH}$ control of proteolysis. J Biosci Bioeng. 116(2):193-198. doi:10.1016/j.jbiosc.2013.02.020.

Dotsenko AS, Gusakov AV, Volkov PV, Rozhkova AM, Sinitsyn AP. 2016. N-linked glycosylation of re- combinant cellobiohydrolase I (Cel7A) from Penicillium verruculosum and its effect on the enzyme activity. Biotechnol Bioeng. 113(2):283-291. doi:10.1002/bit.25812.

Garvey M, Klinger J, Klose H, Fischer R, Commandeur U. 2014. Expression of recombinant cellulase Cel5A from Trichoderma reesei in tobacco plants. J Visualized Exp. (88):e51711. doi:10.3791/51711.

Gusakov AV, Kondratyeva EG, Sinitsyn AP. 2011. Comparison of Two Methods for Assaying Reducing Sugars in the Determination of Carbohydrase Activities. Int J Anal Chem. 2011:1-4. doi:10.1155/2011/283658.

Hadiyanto H, Ariyanti D, Aini AP, Pinundi DS. 2013. Batch and fed-batch fermentation system on ethanol production from whey using Kluyveromyces marxianus. Int J Renewable Energy Dev. 2(3):127-131. doi:10.14710/ijred.2.3.127-131.

Han C, Wang Q, Sun Y, Yang R, Liu M, Wang S, Liu Y, Zhou L, Li D. 2020. Improvement of the catalytic activity and thermostability of a hyperthermostable endoglucanase by optimizing N-glycosylation sites. Biotechnol Biofuels. 13(1). doi:10.1186/s13068-0201668-4.

Ito J, Fujita $\mathrm{Y}$, Ueda $\mathrm{M}$, Fukuda $\mathrm{H}$, Kondo A. 2004. Improvement of cellulose-degrading ability of a yeast strain displaying Trichoderma reesei endoglucanase II by recombination of cellulosebinding domains. Biotechnol Prog. 20(3):688-691. doi:10.1021/bp034332u.

Jin X, Meng N, Xia LM. 2011. Expression of an endo- $\beta$-1,4-glucanase gene from orpinomyces PC-2 in Pichia pastoris. Int J Mol Sci. 12(5):3366-3380. doi:10.3390/ijms12053366.

Kamal S, Khan S, Khan S, Shoaib M, Khan H, Man S, Khan W, Samson M. 2017. Recent view on heterologous expression of thermostable fungal cellulases, focused on expression factory of Pichia Pastoris. Int J Basic Med Sci Pharm. 7(2):43--57.

Knott BC, Haddad Momeni M, Crowley MF, MacKenzie LF, Götz AW, Sandgren M, Withers SG, Staǐšhlberg J, Beckham GT. 2014. The mechanism of cellulose hydrolysis by a two-step, retaining cellobiohydrolase elucidated by structural and transition path sampling studies. J Am Chem Soc. 136(1):321-329. doi:10.1021/ja410291u.

Koontz L. 2014. TCA precipitation. Methods Enzymol. 541:3-10. doi:10.1016/B978-0-12-420119-4.00001$\mathrm{X}$.

Li C, Yang Z, He Can Zhang R, Zhang D, Chen S, Ma L. 2013. Effect of $\mathrm{pH}$ on cellulase production and morphology of Trichoderma reesei and the application in cellulosic material hydrolysis. J Biotechnol. 168(4):470-477. doi:10.1016/j.jbiotec.2013.10.003.

Liang C, Fioroni M, Rodríguez-Ropero F, Xue Y, Schwaneberg U, Ma Y. 2011. Directed evolution of a thermophilic endoglucanase (Cel5A) into highly active Cel5A variants with an expanded 
temperature profile. J Biotechnol. 154(1):46-53. doi:10.1016/j.jbiotec.2011.03.025.

Macauley-Patrick S, Fazenda ML, McNeil B, Harvey LM. 2005. Heterologous protein production using the Pichia pastoris expression system. Yeast 22(4):249270. doi:10.1002/yea.1208.

Nakazawa H, Okada K, Kobayashi R, Kubota T, Onodera T, Ochiai N, Omata N, Ogasawara W, Okada H, Morikawa Y. 2008. Characterization of the catalytic domains of Trichoderma reesei endoglucanase I, II, and III, expressed in Escherichia coli. Appl Microbiol Biotechnol. 81(4):681-689. doi:10.1007/s00253008-1667-z.

Qin Y, Qu Y. 2014. Asn124 of cel5A from Hypocrea jecorina not only provides the $\mathrm{N}$-glycosylation site but is also essential in maintaining enzymatic activity. BMB Rep. 47(5):256-261. doi:10.5483/BMBRep.2014.47.5.166.

Qin Y, Wei X, Liu X, Wang T, Qu Y. 2008. Purification and characterization of recombinant endoglucanase of Trichoderma reesei expressed in Saccharomyces cerevisiae with higher glycosylation and stability. Protein Expression Purif. 58(1):162-167. doi:10.1016/j.pep.2007.09.004.

Ratnakomala S, Fahrurrozi, Yopi. 2019. Enhancement of Cellulase (CMCase) production from marine actinomycetes Streptomyces sp. Bse 7-9: Optimization of fermentation medium by Response Surface Methodology. IOP Conf Ser Earth Environ Sci. 251(1). doi:10.1088/1755-1315/251/1/012005.

Safder I, Khan S, Islam Iu, Kazim M. 2018. Pichia pastoris expression system : a potential candidate to express protein in industrial and biopharmaceutical domains. Biomed Lett. 4(1):1-13.

Samanta S, Basu A, Halder UC, Sen SK. 2012. Characterization of Trichoderma reesei endoglucanase ii expressed heterologously in Pichia pastoris for better biofinishing and biostoning. J Microbiol. 50(3):518525. doi:10.1007/s12275-012-1207-5.

Shental-Bechor D, Levy Y. 2008. Effect of glycosylation on protein folding: A close look at thermodynamic stabilization. Proc Natl Acad Sci USA. 105(24):8256-8261. doi:10.1073/pnas.0801340105.

Sivashanmugam A, Murray V, Cui C, Zhang Y, Wang J, Li Q. 2009. Practical protocols for production of very high yields of recombinant proteins using Escherichia coli. Protein Sci. 18(5):936-948. doi:10.1002/pro.102.

Sun FF, Yang H, Bai R, Fang X, Wang F, He J, Tu M. 2018. Enhanced heterologous expression of Trichoderma reesei Cel5A/Cel6A in Pichia pastoris with extracellular co-expression of Vitreoscilla hemoglobin. J Chem Technol Biotechnol. 93(1):3542. doi:10.1002/jctb.5433. 